\author{
Abstract-Oysters are often cited as \\ "ecosystem engineers" because they \\ modify their environment. Coastal \\ Louisiana contains extensive oyster \\ reef areas that have been harvested \\ for decades, and whether differences \\ in habitat functions exist between \\ those areas and nonharvested reefs \\ is unclear. We compared reef physi- \\ cal structure and resident commu- \\ nity metrics between these 2 sub- \\ tidal reef types. Harvested reefs \\ were more fragmented and had low- \\ er densities of live eastern oysters \\ (Crassostrea virginica) and hooked \\ mussels (Ischadium recurvum) than \\ the nonharvested reefs. Stable iso- \\ tope values $\left({ }^{13} \mathrm{C}\right.$ and $\left.{ }^{15} \mathrm{~N}\right)$ of domi- \\ nant nekton species and basal food \\ sources were used to compare food \\ web characteristics. Nonpelagic \\ Steve Beck ${ }^{1}$ \\ Megan K. La Peyre (contact author) ${ }^{1,2}$ \\ Email address for contact author: mlapey@|su.edu \\ 1 School of Renewable Natural Resources \\ Louisiana State University Agricultural Center \\ 124 Renewable Natural Resources Bldg. \\ Baton Rouge, Louisiana 70803 \\ 2 U.S. Geological Survey \\ Louisiana Cooperative Fish and Wildlife Research Unit \\ School of Renewable Natural Resources \\ Louisiana State University Agricultural Center \\ 124C Renewable Natural Resources Bldg. \\ Baton Rouge, Louisiana 70803
} source contributions and trophic positions of dominant species were slightly elevated at harvested sites. Oyster harvesting appeared to have decreased the number of large oysters and to have increased the percentage of reefs that were nonliving by decreasing water column filtration and benthopelagic coupling. The differences in reef matrix composition, however, had little effect on resident nekton communities. Understanding the thresholds of reef habitat areas, the oyster density or oyster size distribution below which ecosystem services may be compromised, remains key to sustainable management.

Manuscript submitted 9 January 2014. Manuscript accepted 21 May 2015.

Fish. Bull. 113:327-340 (2015)

Online publication date: 9 June 2015. doi: 10.7755/FB.113.3.8

The views and opinions expressed or implied in this article are those of the author (or authors) and do not necessarily reflect the position of the National Marine Fisheries Service, NOAA.
Ecologists have long recognized the importance of "ecosystem engineers" in organizing and maintaining ecosystems through their modification of the availability of resources in the environment (Jones et al., 1994, 1997). Oysters are commonly acknowledged as ecosystem engineers of shallow-water estuaries. Oysters modify the local environment by providing refuge and foraging habitat (Peterson et al., 2003; Coen et al., 2007), by altering local hydrodynamic processes (Lenihan, 1999), and by affecting local water quality (Newell et al., 2005; Piehler and Smyth, 2011; zu Ermgassen et al., 2013). Globally, more than $85 \%$ of oyster reefs have been identified as functionally extinct; disease, poor water quality, and destruction of the physical habitat have been identified as the major proximate causes (Beck et al., 2011). More specifically, the loss of vertical relief and complexity of oyster reefs, largely a result of commercial harvesting, is often cited as the primary factor that drives reef decline (Rothschild et al., 1994; Kirby, 2004).

Changes in the physical structure of reefs through natural processes, such as storm events or human activities associated with harvest, may

\title{
Effects of oyster harvest activities on Louisiana reef habitat and resident nekton communities
}

affect the habitat value of reefs by altering refuge availability and reef community structure (Breitburg, 1999; Soniat et al., 2004; Humphries et al., 2011a). Alteration of the physical structure of reefs directly affects nekton populations by changing the availability of potential habitat, and several studies have highlighted the cascading effects of altered reef properties on trophic dynamics within an oyster reef community (Lenihan et al., 2001; Grabowski and Powers, 2004; Grabowski et al., 2008). Other studies have highlighted the impacts of reduced biomass of oysters, or other filter feeding organisms, on ambient water quality (Cloern, 1982; Fulford et al., 2007; zu Ermgassen et al., 2013).

More than $40 \%$ of the commercial production of the eastern oyster (Crassostrea virginica) in the continental United States occurs in coastal Louisiana estuaries $\left(\mathrm{LDWF}^{1}\right)$, and oysters are the dominant reef-form-

${ }^{1}$ LDWF (Louisiana Department of Wildllife and Fisheries). 2012. Oyster stock assessment report of the public oyster areas in Louisiana: seed grounds and seed reservations. Oyster Data Rep. Ser. 18, 88 p. [Available from Louisiana Dep. Wildl. Fish., P.O. Box 98000, Baton Rouge, LA 70898.] 
ing organism within these estuaries. Harvest activities occur across large areas of oyster reefs (LDWF ${ }^{1}$, but the effects of harvest and management on resident nekton communities, reef structure, and trophic interactions have yet to be quantified. Reefs in this region are characterized as largely subtidal, located in a microtidal, well-mixed environment, and have limited vertical relief $(<50 \mathrm{~cm})$. Therefore, the effects of harvesting on reefs in Louisiana may not be evident in large-scale changes in vertical relief but may be observed more in oyster density and size and in alteration of the reef matrix; oyster density and size, and alteration of the reef matrix may in turn affect refuge value and filtration capacity of an oyster reef (e.g., Summerhayes et al., 2009; La Peyre et al., 2014a).

We compared reef physical structure and resident community metrics on commercially harvested and nonharvested oyster reefs in coastal Louisiana. We quantified and characterized the abundance and composition of the resident nekton community at these oyster reefs. These data were examined to determine whether any differences in resident nekton community structure could be attributed to changes in reef characteristics. Lastly, using stable isotope analyses, we examined whether differences in reef characteristics were associated with differences in food web dynamics, such as the contributions of basal food sources, trophic level, and niche breadth of abundant resident organisms.

\section{Materials and methods}

\section{Study area}

This study was conducted on subtidal reefs located in estuarine shallow-water areas of coastal Louisiana. The coastal bays and estuaries in Louisiana are microtidal (tidal range: $<1 \mathrm{~m}$ ), and most water depths were within a range of 1-4 m. Oyster reefs are located in mid-salinity (salinity range $=5-25$ ) areas within the extensive salt and brackish marsh regions of the Louisiana coast and tend to cover large, heterogeneous areas. The reefs are often extensive and unmapped, and, therefore, they are difficult to delineate. We selected paired harvested and nonharvested sites, all located within similar salinity zones and on public oyster seed grounds that are managed by the Louisiana Department of Wildlife and Fisheries (LDWF ${ }^{2}$, 2010; Fig. 1). For this study, harvest activities included removal of oysters for harvesting, as well as management activities, such as deposition of cultch (i.e., shell and limestone) to provide recruitment substrate. Nonharvested reefs were areas where it has been illegal to harvest oysters for several decades.

Two sites, Sabine Lake and northern Calcasieu Lake, have been closed to harvesting activities for more

\footnotetext{
${ }^{2}$ LDWF (Louisiana Dep.Wildl. Fish.). 2010. Oyster stock assessment report of the public oyster areas in Louisiana: seed grounds and seed reservations. Oyster Data Rep. Ser. 16,92 p. [Available at website.]
}

than 50 years, and they are the only substantial nonharvested subtidal oyster reefs in the state. There is no evidence that cultch deposition has occurred at these sites in the last 50 years. The sites were initially closed for health concerns that no longer persist, and over the last 5 years, there has been enormous pressure to open these areas to harvest. The remaining 2 areas, southern Calcasieu Lake and Sister Lake, are actively harvested with dredges. The most recent cultch deposition in these areas occurred on southern Calcasieu Lake in $2009\left(0.06 \mathrm{~km}^{2}\right.$ of no. 57 limestone), and on Sister Lake in 2009 (0.63 $\mathrm{km}^{2}$ of no. 57 limestone).

Sites were paired on the basis of ecological similarity and not proximity. The sites of northern and southern Calcasieu Lake were sampled as 1 pair; these 2 sites are located within the same waterbody and experience similar salinity regimes (long-term mean salinity: 13.9-16.1) and storm events. Sabine Lake and Sister Lake were paired because of similarities in salinity regimes (long-term mean salinity: 11.9-15.1) and water depths, and both sites are considered interior, large, shallow waterbodies. Although these 2 sites were farther apart from one another geographically than the other paired sites, the assumption was made that if harvest causes significant effects on the habitat, differences that result from harvest activities would be greater than differences associated with actual coastal location.

\section{Data collection}

Field data Reefs were located within each site with side-scan sonar data $\left(\mathrm{ENCOS}^{3}\right)$ for Sabine, Southern Calcasieu, and Sister lake sites and with GPS coordinates from a planting of oyster shell cultch in 1969 for northern Calcasieu Lake. At each of the 4 sites, 3 sample stations, measuring $10 \mathrm{~m} \times 10 \mathrm{~m}$, were established on reef habitat located more than $100 \mathrm{~m}$ from the marsh edge and in the centers of reef areas to remove confounding effects of adjacent habitats and reef edge (Fig. 2; Acosta and Robertson, 2002; Grabowski et al., 2005). At each sample station, reef structure, water quality, and resident nekton communities were sampled according to protocols listed below. All sample stations in Sabine Lake and Sister Lake were sampled twice during summer (July-August) 2010, and all sample stations in northern and southern sites in Lake Calcasieu were sampled twice during fall (SeptemberOctober) 2010.

For each summer sampling event, 3 replicate samples per station were taken (with trays, which are described in the next section); because of high tray loss in the summer, 4 replicate samples were taken per sample station for each fall sampling event to increase

\footnotetext{
${ }^{3}$ ENCOS. 2008. Water bottom assessment of selected portions of public oyster seed grounds within Cameron Parish, Louisiana: Calcasieu and Sabine Lakes, 391 p. Prepared for the Louisiana Dep. Wildl. Fish. [Available from Louisiana Dep. Wildl. Fish., P.O. Box 98000, Baton Rouge, LA 70898.]
} 


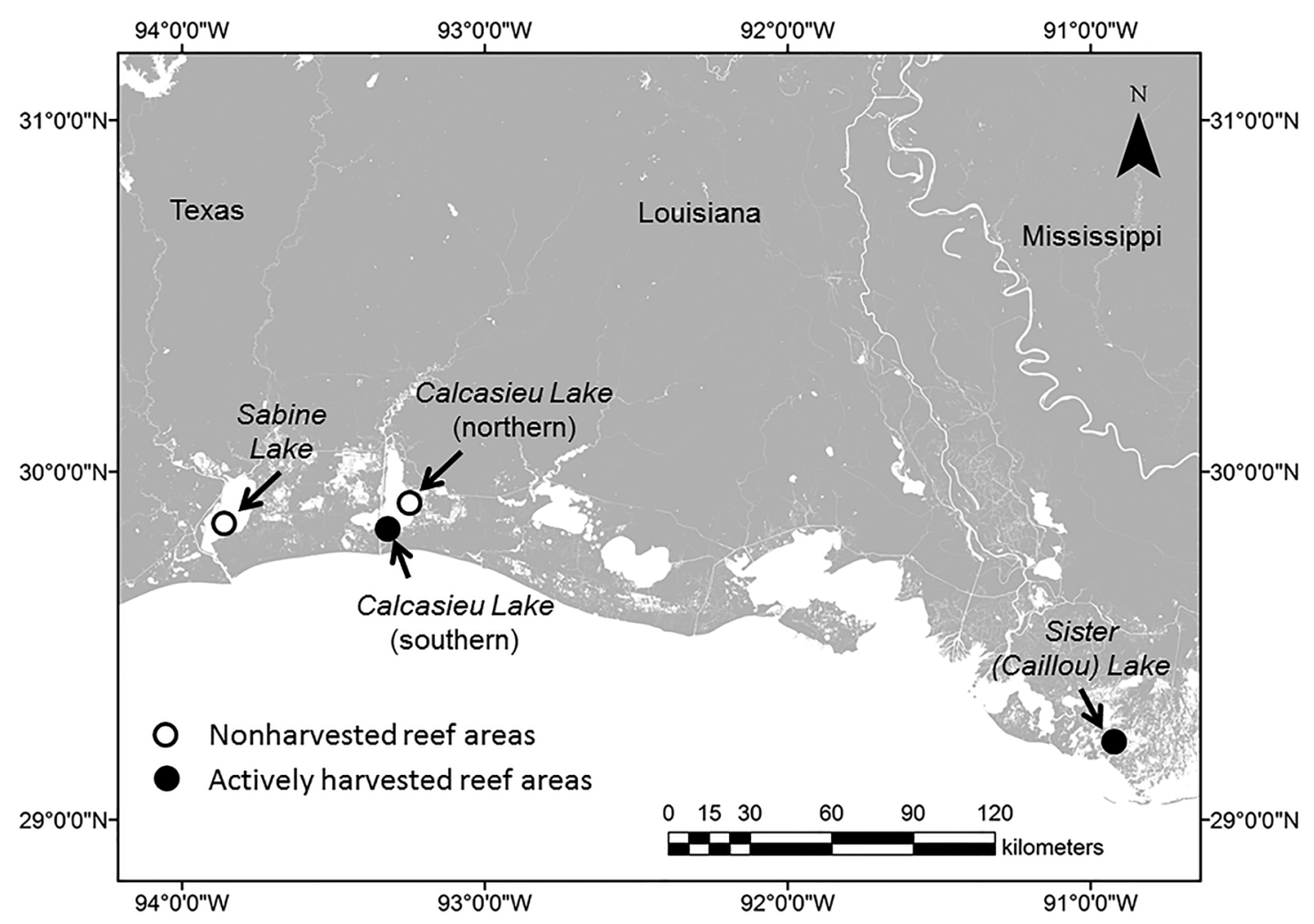

Figure 1

Map of the locations of the 4 sites, Sabine Lake, Sister Lake, and northern and southern Calcasieu Lake, in coastal Louisiana where data were collected in 2010 to describe oyster reef characteristics and associated resident reef community.

the number of trays successfully retrieved (for summer sites: 2 treatments $\times 3$ sample stations $\times 3$ trays $\times 2$ sample events $=36$ samples planned; for fall sites: 2 treatments $\times 3$ sample stations $\times 4$ trays $\times 2$ sample events $=48$ samples planned).

Resident nekton Resident nekton were sampled by using a benthic sample tray with an added mesh drawstring bag that was pulled closed before tray retrieval to prevent escape of mobile organisms. Trays are frequently used to sample oyster reef residents (Lehnert and Allen, 2002; Yeager and Layman, 2011) because of the impracticality of using nets to capture the cryptic species that live within the complex oyster reef matrix. Trays consisted of $0.22-\mathrm{m}^{2}$ plastic trays $(0.47 \mathrm{~m} \times 0.47 \mathrm{~m} \times 0.08$ $\mathrm{m})$, which had their sides and bottoms lined with $3-\mathrm{mm}$ mesh (Fig. 3). At deployment, trays were filled with local oyster reef substrate collected with a small dredge at adjacent reefs more than $100 \mathrm{~m}$ from sampling stations and with the amount needed to displace $5.0 \mathrm{~L}$ of water volume. The volume of $5.0 \mathrm{~L}$ was chosen because it completely fills the tray with substrate.

Deployment times ranged from 1 to 3 weeks because weather affected our ability to retrieve the trays. Lehnert and Allen (2002) and others have found that tray soak times of 2-7 days were adequate for sam- pling resident nekton at subtidal oyster shell habitats and that the communities recruited to trays did not change significantly after 7 days.

Upon retrieval, all organisms were collected, placed on ice, and taken to the laboratory, where they were identified with the use of field guides to the lowest practical taxon (Felder, 1973; Thompson, 1986; Hopkins et al, 1987; Hoese and Moore, 1998; Kells and Carpenter, 2011), measured (total length in millimeters for fish and shrimp, carapace width in millimeters for crabs, and wet-weight in grams), and frozen at a temperature of $-20^{\circ} \mathrm{C}$. If a tray was dumped during retrieval (i.e., some tray contents were lost because of improper net function), organisms were still collected and identified for possible use during stable isotope analyses but were not included in species abundance comparisons. All data for densities of organisms are reported as the number of individuals per square meter.

Reef structure Reef composition was determined by counting and measuring material placed in each tray before deployment. Volume of loose shells and shell clusters was measured by water displacement. Shell clusters were defined as having a minimum of 3 fused oyster shells. The volume of loose shells and clusters provides a proxy for the availability of small and large 

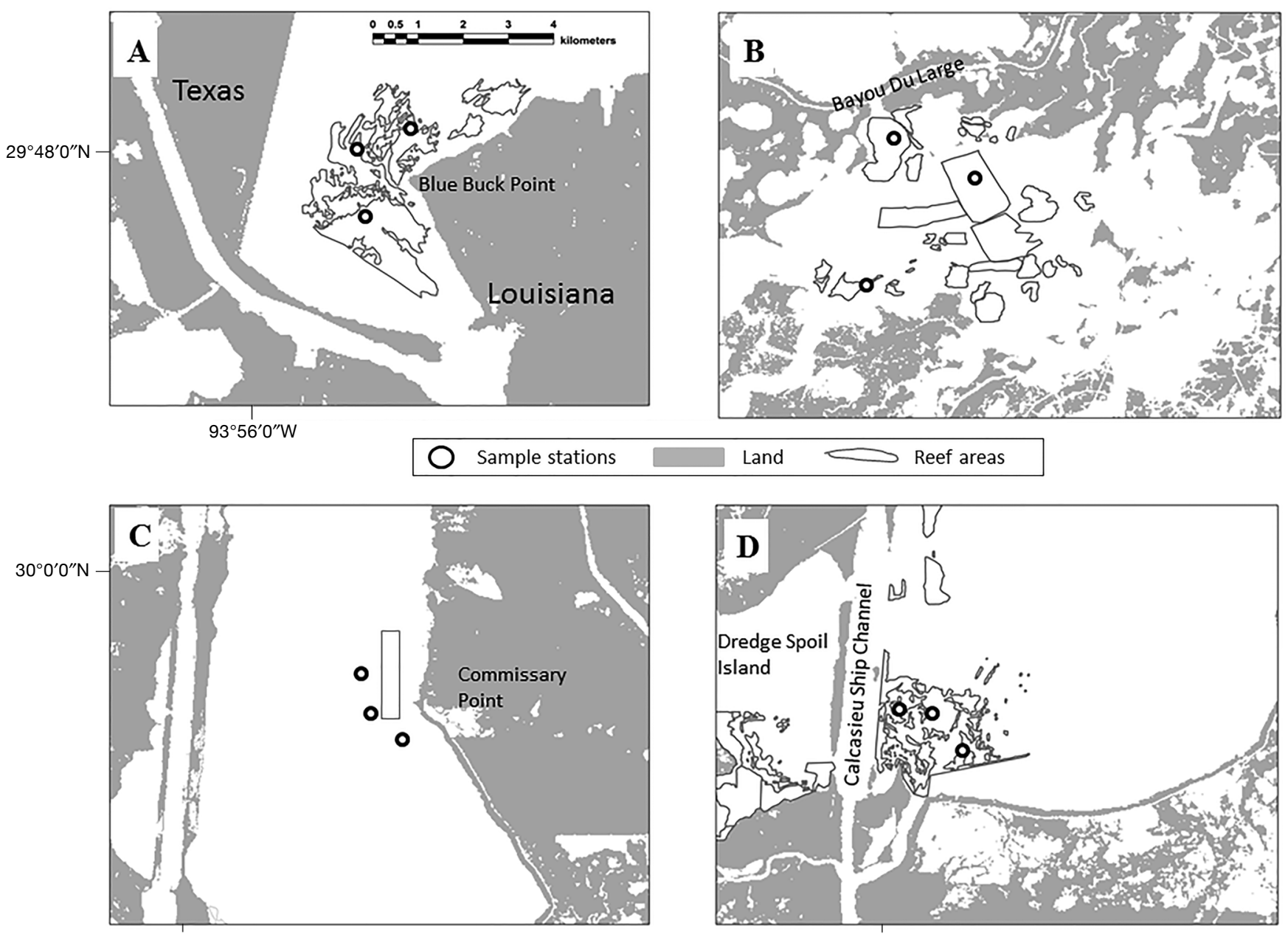

$93^{\circ} 20^{\prime} 0^{\prime \prime} \mathrm{W}$

$93^{\circ} 20^{\prime} 0^{\prime \prime} \mathrm{W}$

Figure 2

Maps of the locations of the 3 stations (o) at each of 4 sites in coastal Louisiana where resident reef communities and reef structure were sampled in 2010: (A) Sabine Lake, (B) Sister Lake, (C) northern Calcasieu Lake, and (D) southern Calcasieu Lake. All reef areas were determined from sonar data, except the reef area in northern Calcasieu Lake, which is based on only GPS coordinates for the footprint of a cultch planting in 1969. The sites at Sabine and Sister lakes were sampled in summer 2010 with 3 samples per station; the northern and southern sites at Calcasieu Lake were sampled in fall 2010 with 4 samples per station.

interstitial reef space, respectively. Total numbers of oysters, of market-size oysters (shell height: $>75 \mathrm{~mm}$ ), and of seed oysters (shell height: 25-75 mm) were counted. At tray retrieval, the number of hooked mussels (Ischadium recurvum) within $1.0 \mathrm{~L}$ of substrate per tray was counted as an indicator of settlement of other (nonoyster) sessile organisms.

Reef integrity and vertical relief were estimated at each sample station. To estimate reef integrity (percentage of area that consisted of solid reef), 20 haphazard measurements were taken by quickly tapping the bottom of the seafloor twice with a long pole and recording the bottom type (solid, mixed shell and mud, or mud). Solid reef was assigned a value of 1.0 , mixed shell and mud was assigned a value of 0.5 , and mud was assigned a value of 0.0 . An index of integrity was calculated by adding the assigned values and dividing by 20 . To measure vertical relief, 20 haphazard depth measurements were taken at each station. The difference between the 2 extreme depth measures was used as an index of vertical relief.

Water quality Upon retrieval of each nekton sampling tray, dissolved oxygen (DO; measured as milligrams per liter), salinity, and temperature (measured in degrees Celsius) data were collected at each sample station at the surface $(\sim 10 \mathrm{~cm}$ below the surface $)$ and the bottom $(\sim 10 \mathrm{~cm}$ above the bottom) of the water column with a YSI Model $85^{4}$ multiparameter sensor (YSI, Inc., Yellow Springs, OH). One surface water sample was collected

\footnotetext{
${ }^{4}$ Mention of trade names or commercial companies is for identification purposes only and does not imply endorsement by the U.S. government.
} 

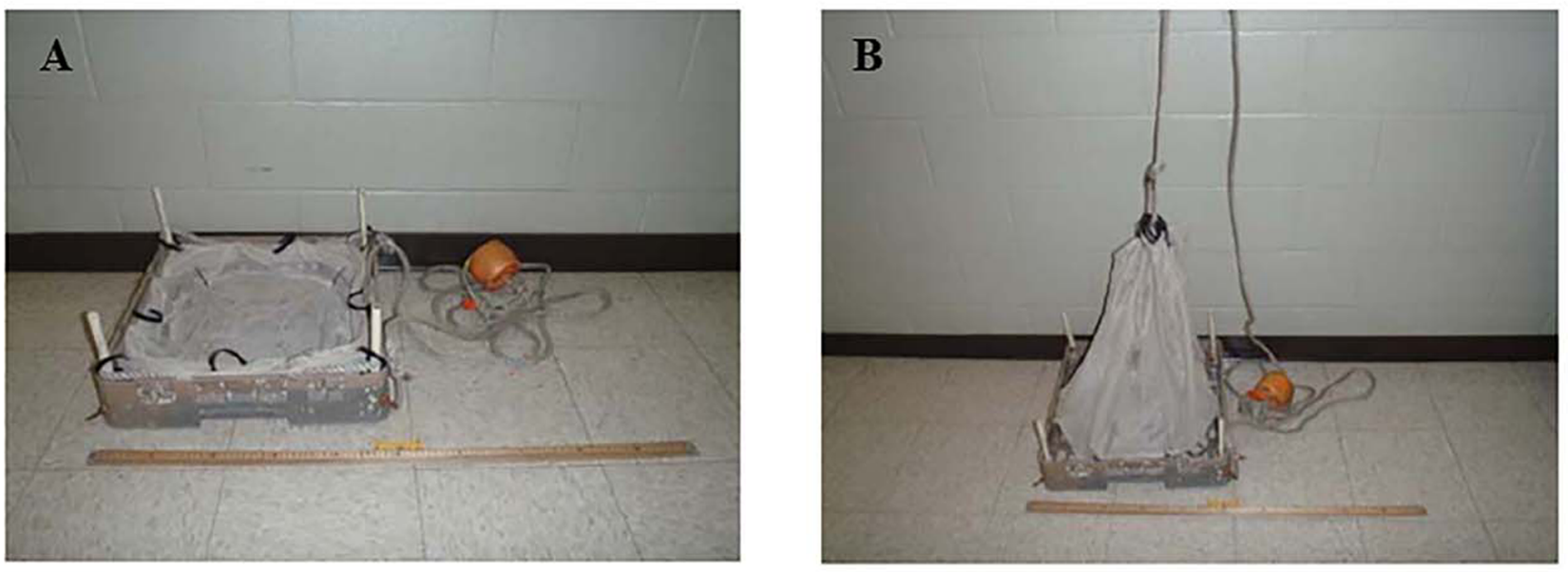

Figure 3

The modified sample tray used for sampling resident communities of oyster reefs in 2010 in coastal Louisiana, showing (A) the mesh drawstring as it would be when deployed and (B) the mesh drawstring pulled for tray retrieval.

at each station with a $250-\mathrm{mL}$, opaque Nalgene bottle, placed on ice, taken to the laboratory, and immediately analyzed for chlorophyll-a (measured in micrograms per liter) (Arar $\left.{ }^{5}\right)$ and total particulate matter (TPM; measured in milligrams per liter) (Rice et al., 2012).

\section{Isotope samples}

Sample collection Resident organisms used for stable isotope analyses were taken from tray samples. For each species found across all sites, only organisms of similar size were used in order to remove any effects of ontogenetic dietary shifts; organisms had to be combined across stations to obtain adequate numbers of each species from each site. Organisms collected included the eastern oyster, hooked mussel, the flatback mud crab (Eurypanopeus depressus), grass shrimp (Palaemonetes spp.), the naked goby (Gobiosoma bosc), the freckled blenny (Hypsoblennius ionthas), and the skilletfish (Gobiesox strumosus). Adductor muscle tissue was used for eastern oysters, and the entire organism was used for hooked mussels (excluding their shells), flatback mud crabs, and grass shrimp. Tail portions were used for naked goby and skilletfish samples, and epaxial muscle tissue was used for freckled blenny.

Samples of basal food sources were collected at each site: fine particulate organic matter (FPOM; <200 $\mu \mathrm{m}$, pelagic source) and dominant marsh plants (nonpelagic, detrital source). For FPOM samples, a 1-L bottle of water was collected from each station (3 samples per

\footnotetext{
${ }^{5}$ Arar, E. J. 1997. Method 446.0: In vitro determination of chlorophylls $a_{1}, b_{1}, c_{1}+c_{2}$ and pheopigments in marine and freshwater algae by visible spectrophotometry, rev $1.2,26 \mathrm{p}$. National Exposure Research Laboratory, Office of Research and Development, U. S. Environmental Protection Agency. [Available at website.]
}

site), filtered through 200- $\mu \mathrm{m}$ mesh, and placed on ice. Three samples clipped from the stems of the marsh plant (Spartina spp.) were collected (20 m apart from each other) from each site and placed on ice. Coarse particulate organic matter (CPOM; >200 $\mu \mathrm{m})$ was collected with a ring-net plankton tow (3-string bridle, 50$\mathrm{cm}$ diameter) fitted with $200-\mu \mathrm{m}$ mesh, pulled at each station for $2 \mathrm{~min}$ at a speed of $2.6 \mathrm{~m} / \mathrm{s}(5 \mathrm{kn})$. Plankton tow contents were placed in a 1 - $\mathrm{L}$ opaque bottle after visible detritus were removed and these bottles were placed on ice and taken to the laboratory for content analysis. FPOM and CPOM samples were filtered through Whatman glass microfiber filters ( $\mathrm{GF} / \mathrm{F}$, precombusted for $3 \mathrm{~h}$ at $450^{\circ} \mathrm{C}$ ) until flow was obstructed, and the filters with the filtrate were frozen at $-20^{\circ} \mathrm{C}$.

\section{Sample preparation and analyses}

All samples were dried to a constant weight at $60^{\circ} \mathrm{C}$, they ground to a powder, and treated to remove lipids. Inorganic carbonates were removed from shrimp, crabs, FPOM, and CPOM through treatment with minute quantities of $1 \mathrm{~N}$ hydrochloric acid until the reaction ceased (Jacob et al., 2005). Lipids were extracted in 2 separate 24-h decantations with hexane at room temperature (Fry et al., 2003). Once they were treated for lipids and inorganic carbonates, samples were placed back into a drying oven at $60^{\circ} \mathrm{C}$ until they reached a constant weight. Faunal tissue samples of $1 \mathrm{mg}$ (standard error [SE] 0.2) and plant tissue samples of 2-3 $\mathrm{mg}$ were weighed for stable isotope analyses. For filtered FPOM and CPOM samples, a small portion cut from the center of the filter was used for analyses. All samples were analyzed for $\delta^{15} \mathrm{~N}$ and $\delta^{13} \mathrm{C}$ by the University of California Stable Isotope Facility with a PDZ Europa ANCA-GSL elemental analyzer (Sercon, Ltd., 
Crewe, UK) interfaced with a PDZ Europa 20-20 isotope ratio mass spectrometer (Sercon, Ltd.).

\section{Data analyses}

Field data Data on water quality, reef structure, and organism abundance (dependent variables) were analyzed separately by season. For all analyses, a significance level of alpha $=0.05$ was used, and results are presented as means with standard errors. Unless otherwise indicated, SAS software, vers. 9.2 (SAS Institute, Inc., Cary, NC) with the GLIMMIX procedure was used for all analyses. Data for water quality, reef structure, and resident oyster reef community were analyzed by using separate generalized linear mixed models (GLMMs) to test for the effects of harvesting (independent variable), with station used as a nested random effect to remove effects of station variation. Bottom DO, salinity, temperature, chlorophyll- $a$, TPM, water depth, and index of integrity were examined by harvesting treatment (actively harvested and nonharvested) with GLMMs that used station as a nested random effect to remove effects of station variation. To examine differences in depth and index of integrity, GLMMs were run with a normal distribution. Densities of market- and seed-size oysters, mussel density, volume of loose shells, and volume of shell clusters were also analyzed by harvest treatment with station as a nested random effect; in addition, a negative binomial distribution with a log-link function was used to account for overdispersion. Significant results for water quality and reef structure parameters were determined with a type-III test of fixed effects. Vertical relief for the 2 harvesting treatments was compared with a 2 -sample $t$-test. Specifically, vertical relief, the difference between the 2 extreme depth measures, was calculated at each station, for 3 stations per site $(\mathrm{N}=6$ [3 stations $\times 2$ sites]). For resident oyster reef communities, GLMMs with a negative binomial distribution and a log-link function to account for overdispersion were run on common species density (species representing $>1 \%$ of total abundance), invertebrate density, fish density, total nekton density (fishes and invertebrates combined), and total number of species. Significant results for resident community parameters were determined with a type-III test of fixed effects.

For examination of species-environment relationships, canonical correspondence analysis (CCA) was performed with CANOCO software, vers. 4.5 (Wageningen UR, Netherlands; ter Braak and Smilauer, 2002) to analyze the relationship between abundances of common resident species and environmental variables (water quality and reef structure), by combining all summer and fall catches. Summer and fall catches were combined to increase the number of samples per species and to focus on species-environment relationships that held true, regardless of season. The number of environmental variables was reduced by using backward selection, sequentially removing the least influential variable until 4 variables remained. Species abundances were $\log (x+1)$ transformed for the CCA to improve normality. A Monte Carlo simulation test was used to determine statistical significance of canonical axes with 1000 simulations on the full model.

Stable isotope data Isotope data were analyzed by season. Isotope values of $\delta^{15} \mathrm{~N}$ to $\delta^{13} \mathrm{C}$ were used to determine contributions of basal food sources (BFSs; marsh plant and FPOM) and consumer trophic positions (dependent variables). Contributions of BFSs to naked goby, freckled blenny, skilletfish, grass shrimp, flatback mud crabs, eastern oysters, and CPOM were determined for each site by using a 2 -source mixing model (Fry, 2006), with the mean $\delta^{13} \mathrm{C}$ values of dominant marsh plants and FPOM from each site. Trophic position (TP) was determined with the following equation:

$$
T P=1+\left(\delta^{15} \mathrm{~N}_{\text {Organism }}-\delta^{15} \mathrm{~N}_{\text {Base }}\right) / T E F \text { (Post, 2002), }
$$

where a trophic enrichment factor (TEF) of $2.54 \%$ was used (Vanderklift and Ponsard, 2003; Caut et al., 2009).

Separate 2 sample $t$-tests were used to test for differences between harvest treatments (independent variable) for the trophic position and BFS contributions of dominant species (Post, 2002; Layman et al., 2007). The convex hull area (the smallest area that incorporates all isotope biplot points for individual species or communities) were calculated and used as a means to represent the trophic diversity within a food web (Layman et al., 2007), but they were not statistically tested because there was only one set of convex hull areas per site (no replication). Convex hull areas were constructed with the convex hull option in the XTools Pro toolbar in ArcMap, the central application of ArcGIS, vers. 9.3.1 (Esri, Redlands, CA). Data for harvest treatments that were not normally distributed were compared with a nonparametric Wilcoxon rank-sum test.

\section{Results}

\section{Field data}

Water quality In the summer, there were no differences in temperature, salinity, and DO between harvested and nonharvested treatments (Table 1). Levels of TPM and chlorophyll- $a$ were higher at the harvested site, Sister Lake $(44.2 \mathrm{mg} / \mathrm{L}$ [SE 3.2] and $18.0 \mu \mathrm{g} / \mathrm{L}$ [SE $2.0])$, than at the nonharvested site, Sabine Lake (17.9 $\mathrm{mg} / \mathrm{L}$ [SE 3.5] and $8.2 \mu \mathrm{g} / \mathrm{L}$ [SE 0.4]).

In the fall, there were no differences in temperature or DO between harvest treatments (Table 1). Chlorophyll- $a$ levels were higher at the harvested site, southern Calcasieu Lake (16.9 $\mathrm{\mu g} / \mathrm{L}$ [SE 0.4]), than at the nonharvested site, northern Calcasieu Lake $(8.6 \mu \mathrm{g} / \mathrm{L}$ [SE 0.3]). Salinity was significantly higher at the nonharvested site (20.0 [SE 0.2]) than at the harvested site (19.2 [SE 0.2]), although the difference was probably not ecologically important. 


\section{Table 1}

Mean measurements of water quality and reef structure for sampled oyster reefs in Louisiana during summer and fall 2010. Degrees of freedom (df) for $F$-values are provided in parentheses and apply to all results except for reef vertical relief, for which $\mathrm{df}=2$ and a 2 -sample $t$-test was used to compare treatments. Significant differences $(P<0.05)$ between harvest treatments are indicated with asterisks $(*)$. Standard errors of the mean are provided in parentheses. NH=not harvested; $\mathrm{AH}=$ actively harvested.

\begin{tabular}{|c|c|c|c|c|c|c|c|c|}
\hline \multirow[b]{2}{*}{ Parameter } & \multicolumn{4}{|c|}{ Summer } & \multicolumn{4}{|c|}{ Fall } \\
\hline & $\begin{array}{c}\text { Sabine } \\
\text { Lake } \\
(\mathrm{NH})\end{array}$ & $\begin{array}{l}\text { Sister } \\
\text { Lake } \\
(\mathrm{AH})\end{array}$ & $F$-value & $P$-value & $\begin{array}{c}\text { North } \\
\text { Calcasieu } \\
(\mathrm{NH})\end{array}$ & $\begin{array}{c}\text { South } \\
\text { Calcasieu } \\
\text { (AH) }\end{array}$ & $F$-value & $P$-value \\
\hline Temperature $\left({ }^{\circ} \mathrm{C}\right)$ & $31.0(0.2)$ & $31.1(0.2)$ & 0.02 & 0.89 & $26.4(0.8)$ & $24.9(1.1)$ & 1.28 & 0.32 \\
\hline Salinity & $13.0(1.2)$ & $12.0(0.4)$ & 0.56 & 0.49 & $20.0(0.2)$ & $19.2(0.1)$ & 12.53 & $0.024^{*}$ \\
\hline Dissolved oxygen $(\mathrm{mg} / \mathrm{L})$ & $5.2(0.3)$ & $4.4(0.3)$ & 0.38 & 0.57 & $6.9(0.1)$ & $6.3(0.2)$ & 2.55 & 0.19 \\
\hline Total particulate & & & & & & & & \\
\hline matter (mg/L) & $17.9(3.5)$ & $44.2(3.2)$ & 9.78 & $0.04^{*}$ & $75.6(1.1)$ & $90.2(5.3)$ & 6.36 & $0.07 *$ \\
\hline Chlorophyll- $a(\mu \mathrm{g} / \mathrm{L})$ & $8.2(0.4)$ & $18.0(2.0)$ & 18.89 & $0.01 *$ & $8.6(0.3)$ & $16.9(0.4)$ & 244.88 & $<0.0001^{*}$ \\
\hline Cluster volume (L) & $3.9(0.1)$ & $2.9(0.2)$ & 3.82 & 0.12 & $4.4(0.1)$ & $1.8(0.1)$ & 221.38 & $<0.0001^{*}$ \\
\hline Loose shell volume (L) & $0.3(0.1)$ & $0.8(0.2)$ & 1.8 & 0.25 & 0 & $2.0(0.1)$ & 80.7 & $0.0008^{*}$ \\
\hline Reef integrity (unitless) & $0.8(0.1)$ & $0.6(0.1)$ & 10.06 & $0.004^{*}$ & $0.9(0.1)$ & $0.8(0.1)$ & 4.52 & $0.04 *$ \\
\hline Reef depth (m) & $2.6(0.02)$ & $1.9(0.03)$ & 10.58 & $0.03^{*}$ & $1.2(0.01)$ & $1.8(0.01)$ & 88.32 & $0.0007^{*}$ \\
\hline Reef vertical relief (m) & $0.20(0.00)$ & $0.17(0.03)$ & $1.00(\mathrm{df}=2)$ & 0.42 & $0.67(0.03)$ & $0.10(0.00)$ & $1.00(\mathrm{df}=2)$ & 0.42 \\
\hline $\begin{array}{l}\text { Total oyster density } \\
\text { (no./tray) }\end{array}$ & $67.0(2.9)$ & $114.8(16.4)$ & 0.83 & 0.41 & $70.5(4.5)$ & $20.7(1.1)$ & 131.22 & $0.0003^{*}$ \\
\hline $\begin{array}{l}\text { Market size oyster density } \\
\text { (no./tray) }\end{array}$ & $32.3(1.8)$ & $9.2(1.1)$ & 40.54 & $0.003^{*}$ & $17.5(0.4)$ & $12.6(0.7)$ & 6.42 & 0.06 \\
\hline $\begin{array}{l}\text { Seed size oyster density } \\
\text { (no./tray) }\end{array}$ & $34.7(2.3)$ & $101.5(16.5)$ & 2.02 & 0.23 & $43.1(3.9)$ & $6.0(0.7)$ & 58.12 & $0.0016^{*}$ \\
\hline Mussel density (no./tray) & $636.4(61.0)$ & $319.2(79.2)$ & 2.39 & 0.2 & $1424.7(22.5)$ & $54.7(5.7)$ & 3724.47 & $<0.0001^{*}$ \\
\hline
\end{tabular}

Reef structure In the summer, there were no differences in the volume of loose shells, shell clusters, vertical relief, total oyster density, seed oyster density, or mussel density (Table 1). Reef integrity, depth, and density of market-size oysters were lower at the harvested site (0.6 [SE 0.1], $1.9 \mathrm{~m}$ [SE 0.03], and 9.2 individuals/tray [SE 1.1], respectively) than at the nonharvested site (0.8 [SE 0.1], $2.6 \mathrm{~m}$ [SE 0.02], and 32.3 individuals/tray [SE 1.8], respectively).

In the fall, there were no differences in vertical relief or in density of market-size oysters (Table 1). Volume of shell clusters was higher at the nonharvested site than at the harvested site: $4.4 \mathrm{~L}$ (SE 0.1) versus $1.8 \mathrm{~L}$ (SE 0.1). Conversely, loose shell volume was higher at the harvested site than at the non-harvested site: $2.0 \mathrm{~L}$ (SE 0.1) versus 0.0 L (SE 0.0). Reef depth was greater at the harvested site than at the nonharvested site: $1.8 \mathrm{~m}$ (SE 0.01) versus $1.2 \mathrm{~m}$ (SE 0.01). Total oyster density, seed oyster density, and mussel density were higher at the nonharvested site (70.5 individuals/tray [SE 4.5], 43.1 individuals/tray [SE 3.9], 1424.7 individuals/tray [SE 22.5], respectively) than at the harvested site (20.7 individuals/tray [SE 1.1], 6.0 individuals/tray [SE 0.7], 54.7 individuals/tray [SE 5.7], respectively).

Nekton community In the summer, 14 tray samples were collected at the nonharvested site, and 12 tray samples were collected at the harvested site (48\% tray retrieval success rate) for a total of 26 trays. Densities of naked goby and estuarine mud crabs (Rhithropanopeus harrisii) were higher at the harvested site (102.8 individuals $/ \mathrm{m}^{2}$ [SE 21.4], 20.1 individuals $/ \mathrm{m}^{2}$ [SE 6.3]) than at the nonharvested site $\left(9.4\right.$ individuals $/ \mathrm{m}^{2}$ [SE 1.6], 0.7 individuals $/ \mathrm{m}^{2}$ [SE 0.4]) (Table 2). The number of invertebrate species and total number of species also were greater at the harvested site (5.5 individuals $/ \mathrm{m}^{2}$ [SE 0.4], 9.0 individuals $/ \mathrm{m}^{2}$ [SE 0.5 ]) than at the nonharvested site (3.4 individuals $/ \mathrm{m}^{2}$ [SE 0.2], 6.2 individuals $/ \mathrm{m}^{2}$ [SE 0.3]).

In the fall, 15 tray samples were collected at the nonharvested site, and 17 tray samples were collected at the harvested site (66\% tray retrieval success rate) for a total of 32 trays. Densities of grass shrimp were greater at the nonharvested site, with a mean of 132.6 individuals $/ \mathrm{m}^{2}$ (SE 17.0) than at the harvested site, with a mean of 65.6 individuals $/ \mathrm{m}^{2}$ (SE 12.7) (Table 2 ). The number of fish species was also greater at the non-harvested site than at the harvested site: 2.5 individuals $/ \mathrm{m}^{2}$ (SE 0.2 ) versus 1.5 individuals $/ \mathrm{m}^{2}$ (SE 0.2$)$.

Species environment The CCA indicated a significant relationship between nekton assemblage structure and environmental variables $(P=0.001$; Fig. 4$)$. The horizontal axis, which explained $58.3 \%$ of the variation 


\section{Table 2}

Mean species density (individuals $/ \mathrm{m}^{2}$ ), mean number of species captured, and $F$-values and $P$-values from generalized linear mixed models run, by site for species collected in summer and fall 2010 at actively harvested (AH) and nonharvested (NH) oyster reefs in Louisiana. Degrees of freedom for $F$-values are provided in parentheses. Significant differences $(P<0.05)$ between harvest treatments are indicated by asterisks (*). Only species that contributed to more than $1 \%$ of the total catch were analyzed statistically. Note that $n$ refers to the number of trays successfully sampled for abundance data. Standard errors of the mean are provided in parentheses.

\begin{tabular}{|c|c|c|c|c|c|c|c|c|}
\hline \multirow[b]{2}{*}{ Scientific name } & \multicolumn{4}{|c|}{ Summer } & \multicolumn{4}{|c|}{ Fall } \\
\hline & $\begin{array}{c}\text { Sabine } \\
\text { Lake } \\
(\mathrm{NH}) \\
n=14\end{array}$ & $\begin{array}{c}\text { Sister } \\
\text { Lake } \\
(\mathrm{AH}) \\
n=12\end{array}$ & $F(1,4)$ & $P$-value & $\begin{array}{c}\text { North } \\
\text { Calcasieu } \\
\text { Lake (NH) } \\
n=15\end{array}$ & $\begin{array}{c}\text { South } \\
\text { Calcasieu } \\
\text { Lake (AH) } \\
n=17\end{array}$ & $F(1,4)$ & $P$-value \\
\hline Gobiosoma bosc & $9.4(1.6)$ & $102.8(21.4)$ & 19.26 & $0.01^{*}$ & $49.7(6.2)$ & $51.9(2.8)$ & 0.06 & 0.82 \\
\hline Hypsoblennius ionthas & $7.8(2.1)$ & $18.2(5.0)$ & 0.08 & 0.8 & $1.5(0.6)$ & $0.8(0.4)$ & 0.27 & 0.63 \\
\hline Gobiesox strumosus & $3.3(0.9)$ & $10.6(2.9)$ & 1.32 & 0.31 & $3.9(0.9)$ & $0.8(0.6)$ & 6.17 & 0.07 \\
\hline Chasmodes bosquianus & $0.7(0.4)$ & $2.3(1.0)$ & & & $1.5(0.6)$ & $0.8(0.4)$ & & \\
\hline Opsanus beta & $3.3(1.2)$ & $1.5(0.9)$ & & & 0 & $0.3(0.3)$ & & \\
\hline Myrophis punctatus & 0 & $2.7(1.6)$ & & & 0 & 0 & & \\
\hline Lutjanus griseus & 0 & $0.4(0.4)$ & & & $0.6(0.4)$ & 0 & & \\
\hline Chaetodipterus faber & $0.3(0.3)$ & $0.4(0.4)$ & & & 0 & 0 & & \\
\hline Gobionellus boleosoma & $0.3(0.3)$ & $0.4(0.4)$ & & & 0 & 0 & & \\
\hline Paralichthys lethostigma & $0.3(0.3)$ & 0 & & & 0 & 0 & & \\
\hline Fish density & $25.4(3.4)$ & $139.2(26.0)$ & 10.17 & $0.03^{*}$ & $57.3(6.2)$ & $54.6(2.8)$ & 0.17 & 0.7 \\
\hline Number of fish species & $2.8(0.3)$ & $3.5(0.4)$ & 1.16 & 0.34 & $2.5(0.2)$ & $1.5(0.2)$ & 11.69 & $0.03 *$ \\
\hline Eurypanopeus depressus & $74.8(12.1)$ & $106.9(15.3)$ & 1.96 & 0.23 & $173.5(17.9)$ & $171.0(14.3)$ & 0.03 & 0.87 \\
\hline Palaemonetes spp. & 207.7(28.8) & $103.9(36.3)$ & 2.02 & 0.23 & $132.6(17.0)$ & $65.6(12.7)$ & 8.98 & $0.04^{*}$ \\
\hline Panopeus simpsoni & $22.4(2.8)$ & $13.7(2.7)$ & 4.91 & 0.09 & $0.9(0.7)$ & $15.8(2.4)$ & 5.97 & 0.07 \\
\hline Callinectes sapidus & 0 & $14.0(5.2)$ & 3.28 & 0.14 & $13.9(4.2)$ & $15.5(5.2)$ & 5.33 & 0.08 \\
\hline Rhithropanopeus harrisii & $0.7(0.4)$ & $20.1(6.3)$ & 19.26 & $0.01^{*}$ & 0 & 0 & & \\
\hline Alpheus heterochaelis & $0.7(0.4)$ & $9.1(2.6)$ & & & $0.3(0.3)$ & $4.6(1.7)$ & & \\
\hline Menippe adina & $0.3(0.3)$ & $4.6(1.3)$ & & & $2.1(0.8)$ & $5.6(1.4)$ & & \\
\hline Farfantepenaeus aztecus & $0.3(0.3)$ & $1.5(1.0)$ & & & 0 & $0.8(0.6)$ & & \\
\hline Petrolisthes armatus & 0 & 0 & & & 0 & $0.3(0.3)$ & & \\
\hline Clibanarius vittatus & 0 & $0.8(0.8)$ & & & 0 & 0 & & \\
\hline Invertebrate density & $306.8(29.8)$ & $274.5(37.8)$ & 0.41 & 0.56 & $323.4(22.9)$ & $279.2(22.3)$ & 1.34 & 0.13 \\
\hline Number of invertebrate & & & & & & & & \\
\hline species & $3.4(0.2)$ & $5.5(0.4)$ & 14.26 & $0.02 *$ & $3.2(0.3)$ & $3.4(0.2)$ & 4.87 & 0.09 \\
\hline Total density & $332.2(29.4)$ & $413.7(55.9)$ & 0.1 & 0.77 & $380.7(21.0)$ & $333.8(24.5)$ & 1.82 & 0.25 \\
\hline Total number of species & $6.2(0.3)$ & $9.0(0.5)$ & 23.9 & $0.008^{*}$ & $5.7(0.3)$ & $6.3(0.3)$ & 1.69 & 0.26 \\
\hline
\end{tabular}

in nekton assemblage (eigenvalue $=0.11$ ), was highly correlated with reef integrity (coefficient of correlation $[r]=-0.69)$ and distinguished species that prefer fragmented reef habitats. Species, such as the bigclaw snapping shrimp (Alpheus heterochaelis) and the estuarine mud crab, were associated with reefs with low integrity values $(<50 \%)$. The vertical axis, which accounted for $27.7 \%$ of the variation (eigenvalue $=0.05$ ), was negatively associated with volume of loose shells $(r=-0.70)$ and positively associated with total number of live oysters $(r=0.70)$, and this axis distinguishes species that prefer live oyster habitats. Species, such as the freckled blenny ( $H$. ionthas) and skilletfish, were strongly positively associated with the number of live oysters.

\section{Stable isotopes}

For the summer sampling, results from a 2-source mixing model indicated that pelagic basal food sources (i.e., FPOM) contributed more to the food web of the resident community on the sampled oyster reefs than the nonpelagic sources (i.e., marsh plant) regardless of harvest treatment (all values of source fractions of FPOM were $>0.50$; Table 3 ). The pelagic source contribution was higher for flatback mud crabs at the nonharvested site (0.65 [SE 0.03]) than at the harvested site $(0.53$ [SE 0.04]). The trophic positions of the hooked mussel, eastern oyster, grass shrimp, skilletfish, and naked goby were elevated at the harvested site compared to the nonharvested site (Fig. 5). 
For the fall sampling, pelagic source contributions were also found to contribute more to the resident community food web than the nonpelagic sources at both harvested and nonharvested sites. Pelagic source contributions were elevated at the harvested site for all organisms except skilletfish. The trophic positions of all organisms were elevated at the harvested site, except that of eastern oysters.

\section{Discussion}

Oyster reef structure, as defined by the extent of solid reef, number and size of live oysters, number of mussels, and interstitial space, can be substantially altered by oyster harvesting activities in coastal Louisiana. Such changes in reef structure did not translate into significant differences in the resident nekton community. Although harvested reefs were more fragmented and sometimes had fewer living oysters and mussels than nonharvested reefs, habitat use and food resources associated with the 2 types of reefs were similar. These results indicate that, although oyster harvest can change the composition of the reef matrix and alter habitat complexity, as long as adequate structural material is maintained, a reef provides suitable habitat for resident communities of small organisms.

Most models of reef degradation from harvest indicate that a loss of vertical relief and complexity lead toward increased stress on an oyster population and loss of oyster reef function (Rothschild et al., 1994; Lenihan and Peterson, 1998; Lenihan, 1999); however, we dealt with subtidal reefs with limited vertical relief. Vertical relief of all reefs in our study ranged from 10 to $20 \mathrm{~cm}$, and reefs were located in depths of $1.2-2.9 \mathrm{~m}$. Whether nonharvested reefs lacked relief because of degradation from historic activities or as a result of environmental constraints is unknown because of a lack of data from the early part of the $20^{\text {th }}$ century.

In contrast with a lack of difference in vertical relief, harvested and nonharvested reefs differed substantially in the composition of reef matrix. As expected, more large live oysters, as well as less reef fragmentation and loose shells, were found at nonharvested sites than at the harvested reef areas. The lack of larger oysters at harvested reefs, a direct consequence of harvest activities, has been documented previously (Lenihan and Micheli, 2000; Lenihan and Peterson, 2004). The increase in fragmentation and loose shells at harvested sites may be due to physical damage from a dredge or due to the frequent placement of shells as cultch by the Louisiana Department of Wildlife and Fisheries within the harvested sites $\left(\mathrm{LDWF}^{2}\right)$. The combined effects of more loose shells, fewer shell clusters, and solid reef area may make the harvested reefs more susceptible to complete reef loss with overharvesting and with the scattering and sedimentation that occurs during storm events. However, as noted previously, flat reefs without small-scale changes in vertical relief are typical of this region. Many of these reefs have existed and been harvested since record keeping began around 1900 .

Despite these differences in the oyster reef matrix, there were no consistent differences between treatments in the overall abundance or diversity of reefassociated nekton communities during fall and summer sampling. This lack of difference in nekton density at reefs with different physical and biological characteristics is similar to that found with other studies of artificial reefs of varying heights (Lenihan et al., 2001), 


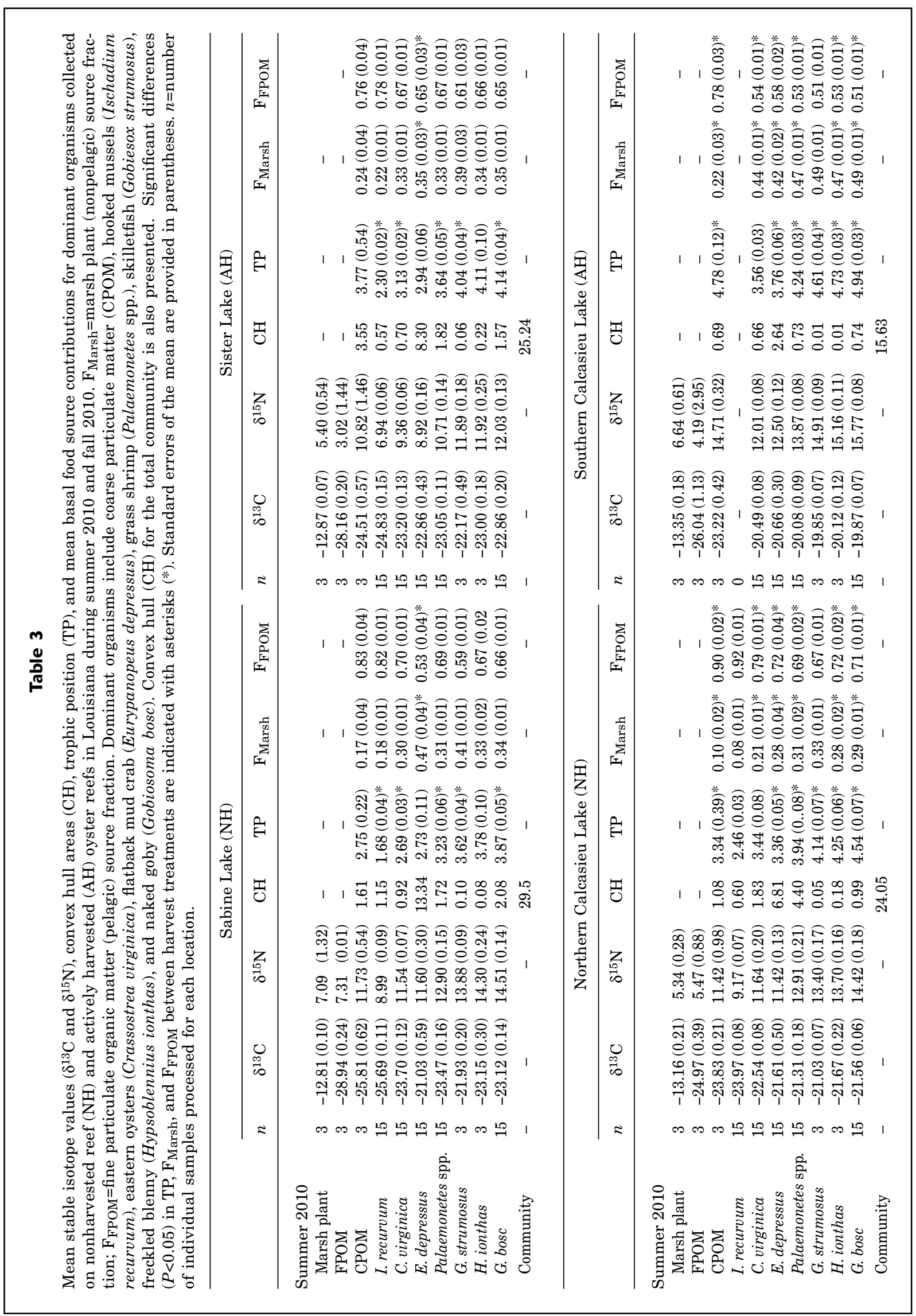



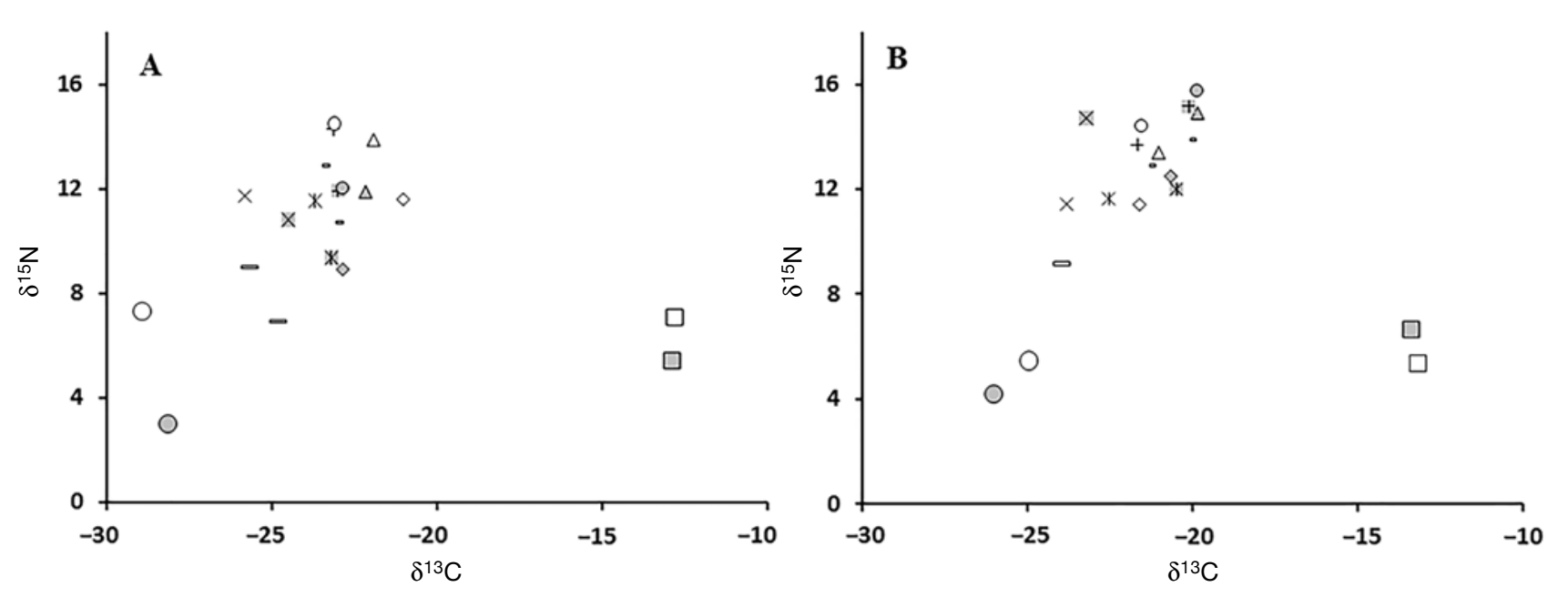

Figure 5

Biplot of mean $\delta^{13} \mathrm{C}$ and $\delta^{15} \mathrm{~N}$ values of basal food sources and dominant faunal species sampled at 4 sites in coastal Louisiana in 2010: (A) Sabine Lake (nonharvested) and Sister Lake (actively harvested) in the summer and (B) northern (nonharvested) and southern (actively harvested) Calcasieu Lake in the fall. Error bars are omitted for simplicity; standard errors of the mean and sample sizes $(n)$ are located in Table 3. Shaded symbols indicate means for harvested sites, and open symbols indicate means for nonharvested sites. Symbols for various organisms: large circle=fine particulate organic matter, square $=$ marsh plant, $x=$ coarse particulate organic matter, large dash=hooked mussel (Ischadium recurvum), crossed $\mathrm{x}=$ eastern oyster (Crassostrea virginica), diamond=flatback mud crab (Eurypanopeus depressus), short dash=grass shrimp (Palaemonetes spp.), triangle=skittlefish (Gobiesox strumosus), plus sign=freckled blenny (Hypsoblennius ionthas), and small circle=naked goby (Gobiosoma bosc).

shell density and vertical relief (Humphries et al., $2011 b)$, and reefs with and without the presence of live oysters (Tolley and Volety, 2005; Summerhayes et al., 2009). Although ecological theory holds that structurally complex habitats are expected to sustain higher densities and more diverse communities than structurally simple ones, defining structural complexity has never been straightforward (Beck, 1998; Bartholomew et al., 2000), and it is not clear whether the harvested and nonharvested sites represented different levels of complexity or just differences in habitat characteristics. No consensus exists as to how to define oyster reef complexity; in some experiments oyster or shell density, vertical relief, or mixtures of unaggregated shells (simple) versus clusters (complex) were used, making it difficult to determine when complexity had actually changed (Grabowski and Powers, 2004; Grabowski et al., 2008; Humphries et al., 2011a).

The use of similar volumes of reef material in the trays may have contributed to the similarity of resident communities at our paired sites, but observed differences in the reef matrix may be important in determining preferred habitats of resident organisms. The use of $5.0 \mathrm{~L}$ of local reef substrate (an amount that corresponds to $22.7 \mathrm{~L} / \mathrm{m}^{2}$ ) to completely fill each sample tray may have resulted in densities of reef material that were beyond a threshold at which differences in nekton abundances can be noted (e.g., Humphries et al., 2011b). Samples obtained by diving on historic, cre- ated, and harvested reefs in the region have provided reef material sample volumes up to $11 \mathrm{~L} / \mathrm{m}^{2}$ in the top $10 \mathrm{~cm}$ of substrate (La Peyre et al., 2014b). The loose matrix of substrate material created by dredging and filling trays may have resulted in increased small interstitial spaces and elevated habitat availability.

Despite this potential criticism, tray substrate differences were observed between harvest treatments. The similarity of species diversity and community composition remains striking and indicates that the sampled harvested and nonharvested areas still support similar nekton communities, although specific niches for certain species were identified by apparent preferences for reef subhabitats. The CCA results indicate that the bigclaw snapping shrimp (Alpheus heterochaelis) and estuarine mud crab are associated with fragmented reef habitats exposed to high levels of chlorophyll-a and that the skilletfish and freckled blenny are associated with the presence of shell clusters (larger interstitial spaces) and high densities of live oysters.

Oysters are known to transfer nutrients from the water column to the benthos; however, the observed decrease in the number and size of live oysters at harvested sites, compared with the number and size at nonharvested sites, may have other trophic effects beyond a decrease in benthopelagic coupling. Filtration rate on a reef is generally held to increase with oyster biomass (Cloern, 1982; Officer et al., 1982; Dame, 1996). In our study, mean levels of chlorophyll-a at 
harvested sites consistently were double the levels at nonharvested sites. The reduced number of large oysters and mussels combined with a probable reduction in overall numbers of other sessile filter-feeding organisms at harvested reefs may contribute to decreased filtration capacity (Dame et al., 1989; Cressman et al., 2003).

Resident communities at both types of oyster reefs appear to depend primarily on pelagic basal food sources (i.e., FPOM). The increase in the fractions of detrital source (i.e., marsh plant), combined with elevated chlorophyll- $a$ levels, indicates a reduction in benthopelagic coupling services at harvested reefs. Benthic microalgae could also contribute to the food webs of oyster reef communities; however, in San Antonio Bay, Texas (also a shallow, turbid estuary), the microphytobenthos contributed less than $2 \%$ of the primary production found in the water column (MacIntyre and Cullen, 1996). Benthic macroalgae, seagrass epiphytes, and upstream terrestrial plant matter can also contribute to the basal food source (Abeels et al., 2012), but these sources were not observed within the studied reef areas.

Trophic position of resident organisms on harvested oyster reefs was slightly elevated in comparison with nonharvested reefs, but trophic order was maintained. Although deriving a TEF specific to these systems may result in different estimates of trophic positions, the trends observed would not change. Differences in trophic position of resident species have also been found between reefs and mud-bottom sites (Quan et al., 2012) and between reefs that were experiencing different riverine exposures (Abeels et al., 2012).

In these instances, trophic shifts may be attributed to increased infaunal diversity associated with combined mud and shell substrate or to increased phytoplankton abundance from riverine inputs. For example, there is evidence that a lower abundance of filter feeders may result in increased zooplankton abundance (Lonsdale et al., 2009) and potentially in a more diverse planktonic community. Elevated chlorophyll-a levels indicate increased phytoplankton abundance at harvested sites. Increased planktonic diversity or higher densities of top planktonic predators (ctenophores) could explain the increase in the trophic position of CPOM at harvested reefs. For the remainder of species, the maintenance of the trophic order for the 2 reef types and the lack of consistent difference in convex hull areas is an indication that the differences in the reef matrix between the harvested and nonharvested sites that were documented in this study did not result in significant changes in feeding behaviors, but the observed shifts in trophic positions and CCA results indicate that reef alteration may have affected the planktonic and infaunal forage base.

Changes in populations of oysters and in the biogenic reefs that these ecosystem engineers create are predicted to have effects on surrounding community structure and ecosystem processes. The results of this study indicate that, on the public oyster grounds in Louisiana, effects of harvesting are subtle for reef types in close proximity (northern and southern Calcasieu Lake) and for those across larger areas (Sabine and Sister lakes). Oyster harvesting practices that alter the reef matrix yet preserve live oysters and reef substrate may still provide important habitat for the resident nekton community. What has yet to be examined is whether there is a threshold of reef habitat area, oyster density, or oyster size distribution below which ecosystem services will be severely compromised.

\section{Acknowledgments}

Funding for this project was provided by the Louisiana Department of Wildlife and Fisheries through support to the Louisiana Cooperative Fish and Wildlife Unit of the U.S. Geological Survey. We thank P. Banks, B. Fry, J. Fleeger, M. Kaller, S. Miller, B. Eberline, J. Furlong, C. Hodnett, C. Duplechain, L. Broussard, G. Decossas, A. Catalanello, M. Fries, W. Sheftall, C. Brown, A. DaSilva, D. Klimesh, H. Beck, and S. Piazza for field and laboratory support. We thank Aswani Volety for comments on an early draft of this manuscript. This manuscript was also significantly improved by extensive reviewer comments. This study was performed under the auspices of Louisiana State University IACUC protocols 08-005 and 11-006.

\section{Literature cited}

Abeels, H. A., A. I. Loh, and A. K. Volety.

2012. Trophic transfer and habitat use of oyster Crassostrea virginica reefs in southwest Florida, identified by stable istope analysis. Mar. Ecol. Prog. Ser. 462:125-142. Article

Acosta, C. A., and D. N. Robertson.

2002. Diversity in coral reef fish communities: the effects of habitat patchiness revisited. Mar. Ecol. Prog. Ser. 227:87-96. Article

Bartholomew, A., R. J. Diaz, and G. Cicchetti.

2000. New dimensionless indices of structural habitat complexity: predicted and actual effects on a predator's foraging success. Mar. Ecol. Prog. Ser. 206:45-58. Article

Beck, M. W.

1998. Comparison of the measeurment and effects of habitat structure on gastropods in rocky intertidal and mangrove habitats. Mar. Ecol. Prog. Ser. 169:165-178. Article

Beck, M. W., R. D. Brumbaugh, L. Airoldi, A. Carranza, L. D. Coen, C. Crawford, O. Defeo, G. J. Edgar, B. Hancock, M. C. Kay, H. S. Lenihan, M. W. Luckenbach, C. L. Toropova, G. Zhang, and X. Guo.

2011. Oyster reefs at risk and recommendations for conservation, restoration, and management. Bioscience 61:107-116. Article

Breitburg, D. L.

1999. Are three-dimensional structure and healthy oyster populations the keys to an ecologically interesting and important fish community? In Oyster reef habitat restoration: a synopsis and synthesis of approaches 
(M. W. Luckenbach, R. Mann, and J. A. Wesson, eds), p. 239-250. Virginia Institute of Marine Science Press, Gloucester Point, VA.

Caut, S., E. Angulo, and F. Courchamp.

2009. Variation in discrimination factors (delta $\Delta^{15} \mathrm{~N}$ and delta $\Delta^{13} \mathrm{C}$ ): the effect of diet isotopic values and applications for diet reconstruction. J. Appl. Ecol. 46:443-453. Article

Cloern, J. E.

1982. Does the benthos control phytoplankton biomass in South San Francisco Bay? Mar. Ecol. Prog. Ser. 9:191-202.

Coen, L. D., R. D. Brumbaugh, D. Bushek, R. Grizzle, M. W. Luckenbach, M. H. Posey, S. P. Powers, and S. G. Tolley.

2007. Ecosystem services related to oyster restoration. Mar. Ecol. Prog. Ser. 341:303-307. Article

Cressman, K.A., M. H. Posey, M. A. Mallin, L. A. Leonard, and

T. D. Alphin.

2003. Effects of oyster reefs on water quality in a tidal creek estuary. J. Shell. Res. 22:753-762.

Dame, R.F., J.D. Spurrier, and T.G. Wolaver.

1989. Carbon, nitrogen and phosphorus processing by an oyster reef. Mar. Ecol. Prog. Ser. 54:249-256.

Dame, R. F.

1996. Ecology of marine bivalves: an ecosystem approach, 272 p. CRC Press, Boca Raton, FL.

Felder, D. L.

1973. An annotated key to crabs and lobsters (Decapoda, Reptantia) from coastal waters of the northwestern Gulf of Mexico. Louisiana Sea Grant Publ. LSU-SG-73-02, 103 p. Center for Wetland Resources, Louisiana State Univ., Baton Rouge, LA. [Available at website.]

Fry, B., D. M. Baltz, M. C. Benfield, J. W. Fleeger, A. Gace, H.

L. Haas, and Z. J. Quiñones-Rivera.

2003. Stable isotope indicators of movement and residency of brown shrimp (Farfantepenaeus aztecus) in coastal Louisiana marshscapes. Estuaries 26:82-97. Article

Fry, B.

2006. Stable isotope ecology, 308 p. Springer Science+ Business Media, New York.

Fulford, R. S., D. L. Breitburg, R. I. E. Newell, W. M. Kemp, and M. Luckenbach.

2007. Effects of oyster population restoration strategies on phytoplankton biomass in Chesapeake Bay: a flexible modeling approach. Mar. Ecol. Prog. Ser. 336:43-61. Article

Grabowski, J. H., and S. P. Powers.

2004. Habitat complexity mitigates trophic transfer on oyster reefs. Mar. Ecol. Prog. Ser. 277:291-295. Article

Grabowski, J. H., A. R. Hughes, D. L. Kimbro, and M. A. Dolan. 2005. How habitat setting influences restored oyster reef communities. Ecology 86:1926-1935. Article

Grabowski, J. H., A. R. Hughes, and D. L. Kimbro.

2008. Habitat complexity influences cascading effects of multiple predators. Ecology 89:3413-3422. Article

Hoese, H. D., and R. H. Moore.

1998. Fishes of the Gulf of Mexico: Texas, Louisiana, and adjacent waters, $2^{\text {nd }}$ ed., 422 p. Texas A\&M Univ. Press, College Station, TX.

Hopkins, T. S., J. F. Valentine, and L. B. Lutz.

1987. An illustrated guide with key to selected benthic invertebrate fauna of the northern Gulf of Mexico, 163 p. Mississippi-Alabama Sea Grant Consortium MASGP-87-0100. Dauphin Island Sea Laboratory, Dauphin Island, AL. [Available at website.]
Humphries, A. T., M. K. La Peyre, and G. A. Decossas. 2011a. The effect of structural complexity, prey density, and "predator-free space" on prey survivorship at created oyster reef mesocosms. PLoS ONE. 6(12): e28339. Article

Humphries, A. T., M. K. La Peyre, M. E. Kimball, and L. P. Rozas.

2011b. Testing the effect of habitat structure and complexity on nekton assemblages using experimental oyster reefs. J. Exp. Mar. Biol. Ecol. 409:172-179. Article

Jacob, U., K. Mintenbeck, T. Brey, R. Knust, and K. Beyer.

2005. Stable isotope food web studies: a case for standardized sample treatment. Mar. Ecol. Prog. Ser. 287:251-253. Article

Jones, C. G., J. H. Lawton, and M. Shachak.

1994. Organisms as ecosystem engineers. Oikos 69: 373-386. [Available at website.]

1997. Positive and negative effects of organisms as physical ecosystem engineers. Ecology 78:1946-1957. Article

Kells, V., and K. Carpenter.

2011. A field guide to coastal fishes from Maine to Texas, 448 p. The Johns Hopkins Univ. Press, Baltimore, MD.

Kirby, M. X.

2004. Fishing down the coast: historical expansion and collapse of oyster fisheries along continental margins. Proc. Natl. Acad. Sci. 101:13096-13099. Article

La Peyre, M. K., J. Furlong, L. A. Brown, B. P. Piazza, and K. Brown.

2014b. Oyster reef restoration in the northern Gulf of Mexico: extent, methods and outcomes. Ocean Coast. Manage.89:20-28. Article

La Peyre, M. K., A. T. Humphries, S. M. Casas, and J. F. La Peyre.

2014a. Temporal variation in development of ecosystem services from oyster reef restoration. Ecol. Eng. 63: 34-44. Article

Layman, C. A., D. A. Arrington, C. G. Montaña, and D. M. Post. 2007. Can stable isotope ratios provide for community-wide measures of trophic structure? Ecology 88:42-48. Article

Lehnert, R. L., and D. M. Allen.

2002. Nekton use of subtidal oyster shell habitat in a southeastern U.S. estuary. Estuaries 25:1015-1024. Article

Lenihan, H. S.

1999. Physical-biological coupling on oyster reefs: how habitat structure influences individual performance. Ecol. Monogr. 69:251-276. Article

Lenihan, H. S., and F. Micheli.

2000. Biological effects of shellfish harvesting on oyster reefs: resolving a fishery conflict by ecological experimentation. Fish. Bull. 98:86-95.

Lenihan, H. S., and C. H. Peterson.

1998. How habitat degradation through fishery disturbance enhances impacts of hypoxia on oyster reefs. Ecol. Appl. 8:128-140. Article

2004. Conserving oyster reef habitat by switching from dredging and tonging to diver-harvesting. Fish. Bull. 102:298-305.

Lenihan, H.S., C. H. Peterson, J. E. Byers, J. H. Grabowski, G. W. Thayer, and D. R. Colby.

2001. Cascading of habitat degradation: oyster reefs invaded by refugee fishes escaping stress. Ecol. Appl. 11:764-782. Article 
Lonsdale, D. J., R. M. Cerrato, R. Holland, A. Mass, L. Holt, R.

A. Schaffner, J. Pan, and D. A. Caron.

2009. Influence of suspension-feeding bivalves on the pelagic food webs of shallow, coastal embayments. Aquat. Biol. 6:263-279. Article

MacIntyre, H. L., and J. J. Cullen.

1996. Primary production by suspended and benthic microalgae in a turbid estuary: time scales of variability in San Antonio Bay, Texas. Mar. Ecol. Prog. Ser. 145:245-268. Article

Newell, R. I. E., T. R. Fisher, R. R. Holyoke, and J. C. Cornwell. 2005. Influence of eastern oysters on nitrogen and phosphorus regeneration in Chesapeake Bay, USA. In The comparative roles of suspension feeders in ecosystems. NATO Sci. Ser.: IV Earth Enviorn. Sci., vol. 47 (R Dame and S. Olenin eds.), p. 93-120. Springer, Netherlands. Article

Officer, C. B., T. J. Smayda, and R. Mann.

1982. Benthic filter feeding - a natural eutrophication control. Mar. Ecol. Prog. Ser. 9:203-210.

Peterson, C. H., J. H. Grabowski, and S. P. Powers.

2003. Estimated enhancement of fish production resulting from restoring oyster reef habitat: quantitative valuation. Mar. Ecol. Prog. Ser. 264:249-264. Article

Piehler, M. F., and A. R. Smyth.

2011. Habitat-specific distinctions in estuarine denitrification affect both ecosystem function and services. Ecosphere 2:article 12. Article

Post, D. M.

2002. Using stable isotopes to estimate trophic position: models, methods, and assumptions. Ecology 83:703-718. Article

Quan, W., A. T. Humphries, L. Shi, and Y. Chen.

2012. Determination of trophic transfer at a created intertidal oyster (Crassotrea ariakensis) reef in the Yangtze River Estuary using stable isotope analyses. Estuar. Coasts 35:109-120. Article

Rice, E. W., R. B. Baird, A. D. Eaton, and L. S. Clesceri (eds.). 2012. Standard methods for the examination of water and wastewater, $22^{\text {nd }}$ ed., 1496 p. American Public Health Association, Washington, D.C.
Rothschild, B. J., J. S. Ault, P. Goulletquer, and M. Héral.

1994. Decline of the Chesapeake Bay oyster population: a century of habitat destruction and overfishing. Mar. Ecol. Prog. Ser. 111:29-39.

Soniat, T. M., C. M. Finelli, and J. T. Ruiz.

2004. Vertical structure and predator refuge mediate oyster reef development and community dynamics. J. Exp. Mar. Biol. Ecol. 310:163-182. Article

Summerhayes, S. A., M. J. Bishop, A. Leigh, and B. P. Kelaher. 2009. Effects of oyster death and shell disarticulation on associated communities of epibiota. J. Exp. Mar. Biol. Ecol. 379:60-67. Article

ter Braak, C. J. F., and P. Smilauer.

2002. CANOCO reference manual and CanoDraw for Windows user's guide: software for canonical community ordination (vers. 4.5), 500 p. MicrocomputerPower, Ithaca, NY.

Thompson, B. A.

1986. Identification guide to selected estuarine fishes of Louisiana. Louisiana Sea Grant College Program and Louisiana State Univ. Coastal Fisheries Institute LSU-CFI-86-05, 29 p. Center for Wetlands Resources, Louisiana State Univ., Baton Rouge, LA. [Available at website.]

Tolley, S. G., and A. K. Volety.

2005. The role of oysters in habitat use of oyster reefs by resident fishes and decapod crustaceans. J. Shellfish Res. 24:1007-1012. Article

Vanderklift, M. A., and S. Ponsard.

2003. Sources of variation in consumer-diet ${ }^{15} \mathrm{~N}$ enrichment: a meta-analysis. Oecologia 136:169-182. Article

Yeager, L. A., and C. A. Layman.

2011. Energy flow to two abundant consumers in a subtropical oyster reef food web. Aquat. Ecol. 45:267-277. Article

zu Ermgassen, P. S. E., M. D. Spalding, R. E. Grizzle, and R. D. Brumbaugh.

2013. Quantifying the loss of a marine ecosystem service: filtration by the eastern oyster in US estuaries. Estuar. Coasts 36:36-43. Article. 